\title{
Mining technology in mining - based on the cream filling
}

\author{
Zhengkang Shi \\ School of Resource and Environment Project, Wuhan University of Technology, Wuhan, 430070, \\ China
}

Keywords: Mining process, paste filling, mining operations.

\begin{abstract}
With the development of the mining industry, mining technology is constantly innovation. Mining technology plays a vital role in the mining industry. Mining technology is reasonable or not, and the level of mining companies technology, directly have impact on the overall effectiveness of the mining companies, even threatening the lives and property of mining operations personnel. Therefore, in order to better enhance the application of the mining technology, we must effectively control the features of mining technology in mining operations. Take mining processes such as mechanized mining method, mining method and special padding method, and apply it with mining operations among the mining operations to continuously improve the effectiveness of the promotion. This article focuses on the cream filling method.
\end{abstract}

\section{Introduction}

Mining is an important part of human civilization and social progress and economic development. Human development and utilization of mineral raw materials for social development and progress of civilization plays a huge role in promoting. However, the period of modern society is in rapid development of modern science. The development and utilization of mineral resources is the largest, exploitation of mineral resources are being developed by the shallow depth of easy to difficult mining direction. While the mining industry is also facing a lot of problems ,such as rock burst, surface subsidence, deep rock burst, cost, environmental, geological disasters and other issues, and people are constantly looking for safe, economical, efficient and environmentally friendly mining methods to solve these problems.

Mining technology into a variety, compared with other conventional mining methods, mine filling main advantage preclude performance in reducing ore dilution rate, improve the efficiency of ventilation, fire prevention down hole control rock burst and surface subsidence, etc., so this article focuses on the paste filling technology were discussed.

\section{Mining Technology Overview}

\subsection{Premise of Mining Technology Used in Mining Operations}

With the development of low carbon environmental protection, ecological green health concept has been widely accepted, and gradually penetrated into all walks of life into. Thus, as in the context of the new era of mining enterprises must always adhere to low-carbon environment, the basic principles of ecology green mining technology in the application process, achieve low-carbon mining and green mining. Pay attention to environmental protection in the mining process, for the existence of environmental problems must be timely treatment. On this basis, adopt modern green ecological, efficient and environmentally friendly mining process equipment and technology.

Only in this way, company will stand in an increasingly competitive market, to enhance the core competitiveness of enterprises, and promote sustainable development of enterprises and the whole industry. Thus, carbon mining, green mining is not only the important initiatives to improve the enterprise's core competitiveness, is also a prerequisite for the application of mining technology to mining operations. It is the future trend of the development of China's mining and important direction. 
In recent years, padding technique in the world have wide applications, Table 1 shows the development time of the node foreign filling technology.

Table 1: Development time of the node foreign filling technology

\begin{tabular}{|c|c|c|c|c|}
\hline Time (year) & $\begin{array}{c}\text { Water and } \\
\text { sediment filling }\end{array}$ & Dry filling & cemented filling & paste filling \\
\hline 1864 & $\begin{array}{c}\text { USA } \\
\text { Pennsylvania }\end{array}$ & & & \\
\hline 1930 & & $\begin{array}{l}\text { Canadian Horn } \\
\text { mines Ltd }\end{array}$ & & \\
\hline 1962 & & & $\begin{array}{l}\text { Australia Mount } \\
\text { Isa Copper Mine }\end{array}$ & \\
\hline 1978 & & & & $\begin{array}{l}\text { Germany grunc } \\
\text { lead zinc mine }\end{array}$ \\
\hline
\end{tabular}

\subsection{Features of Mining Technology}

In the process of mining operations in order to strengthen the application of mining technology, as mining operations personnel must have a comprehensive understanding of its characteristics.

Firstly, the ore in natural is the main raw material mining, this shows that we cannot arbitrarily choose mining address, Minerals cannot regenerate, and be input. Mine mineral reserves, economic productivity and mining companies have closely link.

Secondly, mining machinery and equipment and personnel have greater mobility. It often with the progress of mining and processing of the object changes in circumstances and transferred. Mining, mining the relationship among the three prospective and mining work is coordinated with each other so as to ensure smooth production of the mine. If the relationship between the three cannot do mutual coordination, so would have a range of adverse reactions, such as mining disorders, such as mine production.

Third, with the development of the mining industry, mining operations will inevitably exhibit high quality mineral depletion, mining conditions become more and more severe, mineral quality is getting worse, and the increasingly high cost of mining. Inferior mineral exploitation, will rock mixed with the ore, resulting in ore dilution, thereby reducing the mining quality, efficiency and effectiveness; When inferior mineral exploitation, but also encounter the situation cannot be part of the ore mined, which further increased the loss of business.

Fourth, complex storage of mineral resources, quality uneven distribution of industrial reserves of mineral resources make easy changes, resulting in mine design is difficult to achieve standardization, with the mining project is a complex, long mine construction period, the amount of investment in large systems engineering, This further increases the risk of investment in mining enterprises;

Fifth, the distribution of mineral resources, primarily in two forms, one exposed on the surface, a deep beneath the surface. Mining jobs with labor demand, poor working conditions, lack of security features to protect.

\section{Paste Filling Technology}

\subsection{Technical Analysis}

Mining operations in the production practice, people have summed up the filling mining safety, restore, efficient, environmentally friendly and reduce the dilution rate, applicability, and many other advantages. Filling Mining from birth has been a hundred years of history, it has be one of the three major mining methods preclude. This kind of preclude mining methods in many different geological environments have had a history of successful application.

Depending on the filling material will fill preclude mining technology into dry filling, water, sand filling, concrete filling, fill tailings, tailings backfill, waste rock cemented filling, cream filling, quick-setting high water filling and other waste filling, etc. According to fill the required power division can be divided into mechanical filling, wind filling, water filling, millet and filling pressure. Depending on the direction of the recovery process and fill mining method can be divided on the 
approach to layering filled, up, down to the layering, the next approach to filling, filling scarps, wall brackets and filling boxes filling and more kinds of filling forms of technology.

Classification as shown below:

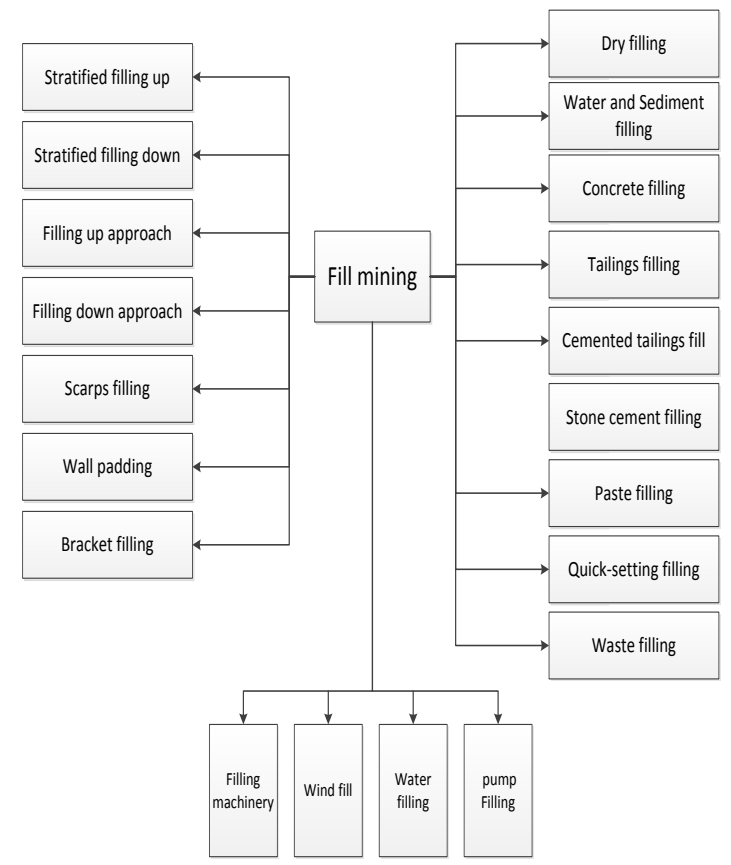

Fig. 1: Filling method Classification

Refers to the so-called cream is mixed with solid particles, cementitious materials and water, it has segregation ability, no critical velocity, good self-reliance. Water content is generally between $10 \%$ to $20 \%$.Compared with the traditional filling technology, paste filling mining method has the following characteristics:

In favor of environmental protection, a wide range of filling materials, can be wholly mine tailing back fill and other solid waste.

Improve strength of the filler, paste filling material than the traditional filling material loaded with a higher density, filling body can be formed with good mechanical properties. Filling distance, filling times without filling line control, pumpable.

To improve the work environment of stope, paste has good segregation resistance, after filling stope without dehydration.

\subsection{Paste filling Characteristics}

Paste filling materials are usually made of cement as a cementitious material, mixed tailings, water, and a new material made additives. In recent years, this material in the international underground mine preclude the application of more general use. Paste filling technology with the traditional filling techniques compared to the economic and environmental benefits are showing superiority.

Ore mining process, filling body must be stable to ensure the safety of mining work carried out. Analysis of the relationship between the various factors that affect the quality of paste filling, filling improve quality, optimize the structure of the paste backfill ratio, which are very important.

(1)Paste block characterization

Paste filling slurry mainly by filling aggregate, gelling agents, water. Preliminary tailings are used as filling the whole aggregate, meet Bian charge ratio of 1: 1 design requirements. Particle size and grain size of full tailings can be shown in the figure below.

The following table shows the basic properties of materials:

Table 2: Development time of the node foreign filling technology

\begin{tabular}{|c|l|c|c|c|}
\hline $\begin{array}{c}\text { Density } \\
\mathrm{Kg} / \mathrm{m} 3\end{array}$ & $\begin{array}{l}\text { Mortar } \\
\text { concentration\% }\end{array}$ & $\begin{array}{c}\text { Mortar density } \\
\mathrm{Kg} / \mathrm{m} 3\end{array}$ & Tailings yield \% & $\begin{array}{c}\text { Grinding fineness } \\
-0.074 \mathrm{~mm}\end{array}$ \\
\hline 3800 & $15 \sim 20$ & $1400 \sim 1600$ & $30 \sim 35$ & $>=68 \%$ \\
\hline
\end{tabular}




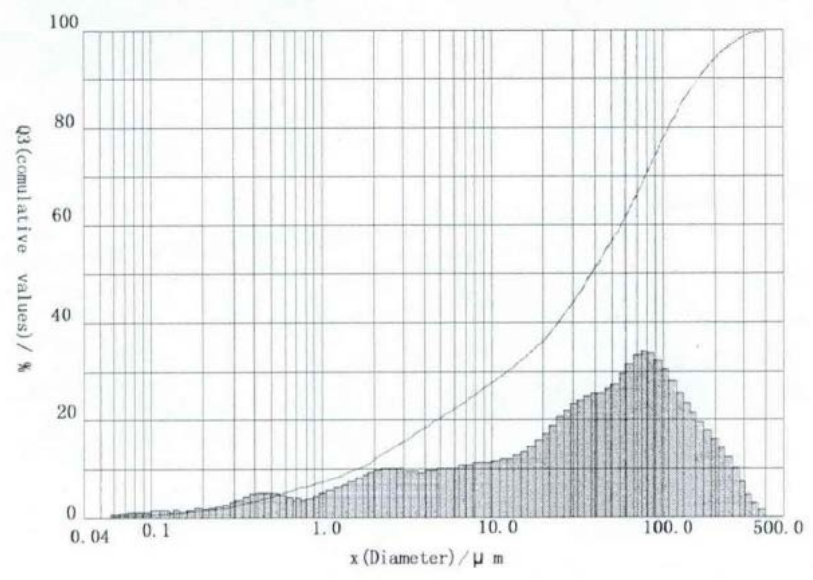

Fig. 2 : Particle size and grain size of full tailings

The following figure shows the gray sand ratio of 1: 4 filling material parameters correlated.
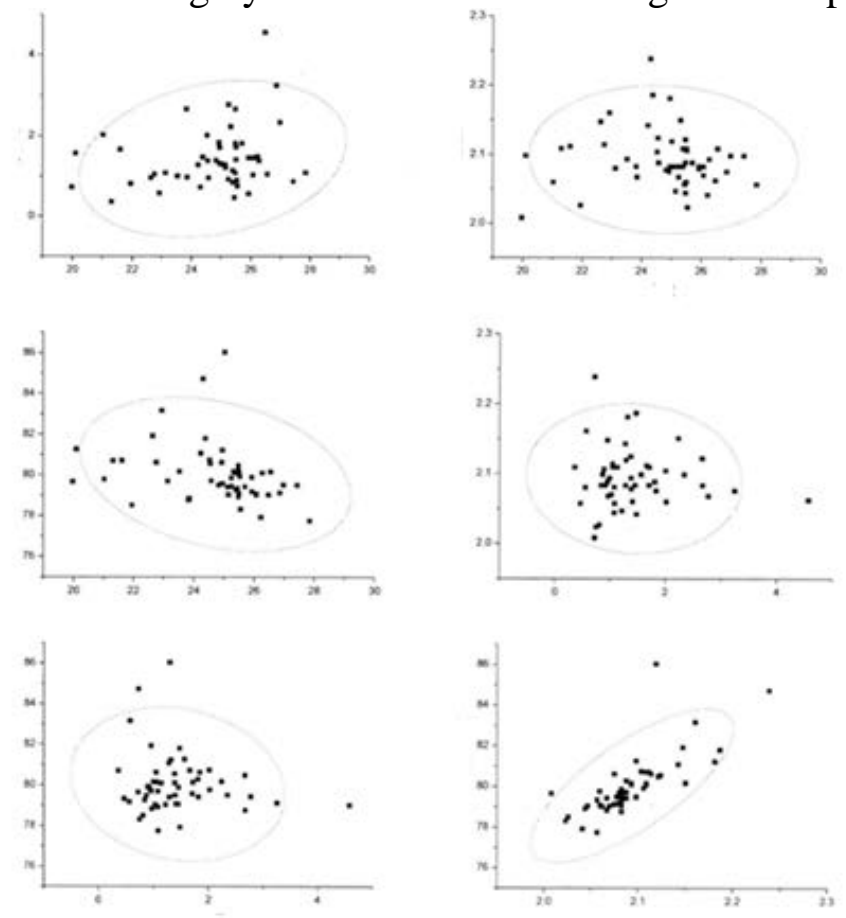

Fig. 3: Filling material parameters correlated

In the drawing, correspondence respectively is slump - Analysis of water rates,Slump density,Slump - concentration,Analysis of water rate - density,Analysis of water rate concentration,Bulk density - concentration.

(2)Strength properties for time

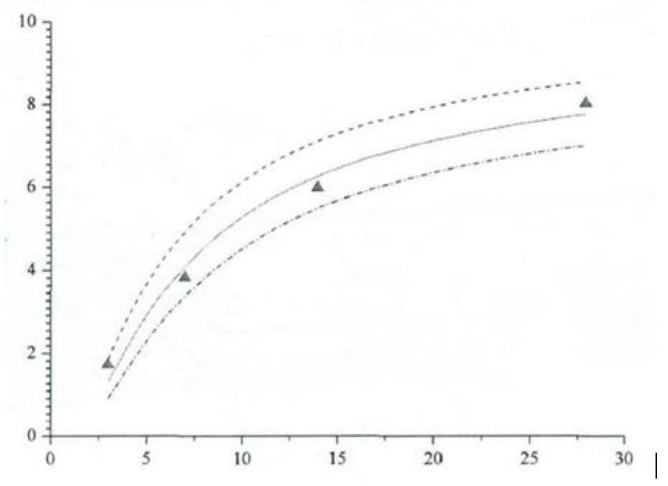

Triangles represent the mean, two dashed lines are the upper and lower limits, the solid line is the fitted values. 


\section{Application of the Paste Filling Technology to Mining Operations}

Paste filling mining technology used in mining operations, primarily individually applied filler in advance when stope mined areas fill mining process. Sometimes in order to maintain the mined-out area, filling material can also be taken in conjunction with the way the bracket is filled.

The filling mined areas to take advantage of the body has been formed to manage the land filling pressure, to better control the surrounding rock caving and surface subsidence.

In mining operations, no matter what kind of mining technology we use, we need to first ensure safety. Only in this way, can we effectively use various mining technology. The impact on environmental from the coal production must attract people's attention. Conscientiously implement low carbon environmental protection, green eco concept, improve the efficiency and rationality of mining technology applications, and improve the quality of mining operations, which significantly enhance the economic and social benefits.

Today, science and technology has made tremendous progress. In the development of the mining undertakings, some companies have begun to green mining technology for mining operations. However, when they are widely used in large coal mining projects, there have been some problems. Therefore, in order to promote China's coal mines can get better, faster development, We must discuss the development trend of green mining technologies to be used in to the filling operation ,in order to have better exploitation of mineral resources.

\section{Conclusions}

Through the above discussion, the analysis shows that the mining technology used in mining operations, has very important significance. In this paper, the application of mining technology, a detailed analysis of the filling mining technology classification, characteristics, and analyzes the characteristics of the paste fill technology. Ultimately, Analysis the paste fill technology in mining operations, And tells the trends of the development of mining technology.

\section{References}

[1] Benzaazoua M, Belem T, Bussiere B. Chemical factors that influence the performance of mine sulphidic paste back flll[J]. Cement and Concrete Research, 2002, 32(7):1133-1144.

[2] Deschamps T, Benzazoua M, Bussiere B, et ai. Micro structural and geo chemical evolution of paste tailings in surface disposal conditions [J]. Minerals Engineering, 2008, 21(4):341-353.

[3] M F, T B, M B.: 58th Canadian Geo technical and 6th Joint IAH-CNC and CGS Groundwater Specialty Conferences, Saskatoon, Saskatchewan, 2005[C].

[4] MF, M B, E S. Mix proportioning of underground cemented paste back fill [J].International Journal of Tunnelling and Underground Construction, 2008, 23:80-90.

[5] Ouellet S, Bussiere B, Aubertin M, et al. Micro structural evolution of cemented paste back fill: Mercury intrusion porosimetry test results [J]. Cement and Concrete Research, 2007, 37(12):1654-1665.

[6] Yilmaz E, Kesimal A, Deveci H, et al. The factors affecting the performance of paste back fill; physical, chemical and mineralogical characterization: First Engineering 